\title{
Review: The Orthography of Geographical Names
}

\section{Author(s): J. C. Dalton}

Review by: J. C. Dalton

Source: The Geographical Journal, Vol. 1, No. 5 (May, 1893), pp. 431-437

Published by: geographicalj

Stable URL: http://www.jstor.org/stable/1774068

Accessed: 26-06-2016 01:10 UTC

Your use of the JSTOR archive indicates your acceptance of the Terms \& Conditions of Use, available at

http://about.jstor.org/terms

JSTOR is a not-for-profit service that helps scholars, researchers, and students discover, use, and build upon a wide range of content in a trusted digital archive. We use information technology and tools to increase productivity and facilitate new forms of scholarship. For more information about JSTOR, please contact support@jstor.org.

The Royal Geographical Society (with the Institute of British Geographers), Wiley are collaborating with JSTOR to digitize, preserve and extend access to The Geographical Journal 
was ridden down not more than twenty years ago; but the camel will soon be undisputed lord of all the deserts. Here is clearly marked the footstep of the camel in his migration westward from Asia. History even allows us to fix the date when it was planted here. And the intimate connection which exists among his pastoral masters, between botany and geography, enables us to estimate the effect of the camel's arrival here.

\title{
THE ORTHOGRAPHY OF GEOGRAPHICAL NAMES.*
}

\author{
By Lieut.-Colonel J. C. DALTON, R.A.
}

To all who are interested in the vexed question of the orthography and pronunciation of geographical names, this interesting contribution will be welcome. The subject is one which is perhaps not so freely taken up as its importance to geographers and cartographers deserves, and we must be all the more grateful to those who, like Dr. Köppen, have devoted their attention to it, and who give to the geographical student the benefit of their knowledge and study in this direction. The pamphlet under review consists of some thirty-nine pages of closelyprinted matter, and is in fact a paper laid before the German "Geographentag" (April 1893) by the author.

Though a complete translation would be very interesting, I have limited myself to a fairly full précis, owing to the imperative necessity for economising space.

The author divides his article into five main headings, which I propose to give in succession with as much brevity as I feel justified in using :-

1. The development of the question since 1885.-After pointing out the inconvenience of having several ways of writing geographical names, the author assigns the credit to the Royal Geographical Society of London and the British Admiralty for having, in 1885, been the first to attempt to grapple with the question, remariing that the English system of considering the "vowels as in Italian and the consonants as in English" is nearly identical with the principle followed in 1876 by the German Eastern Asiatic Company, who, on their part, had taken their ideas from 'Hepburn's Japanese-English Dictionary.'

In April, 1886, the Paris Geographical Society followed with rules which in many points agreed with the English, but which, unfortunately, have not found much support amongst French writers. However, in June, 1887, the French Admiralty accepted this system, and in 1888 the German Hydrographical Department published similar rules. The German "Geographentag" entered this subject on the programme for their meeting in Berlin in 1889, but hardly touched on it Though not ripe for discussion at the Berne Congress in 1891, it is hoped that it will be considered at the next assembly of this international Congress.

* 'Die Schreibung Geographischer Namen: Vorschlag an den Deutschen Geo. graphentag von 1893.' Von Professor Dr. W. Köppen. Hamburg 1893. 
In the autumn of 1890 the Government of the United States assembled a "Board on Geographic Names,"* which consulted all the different foreign hydrographic departments, and published their answers in a voluminous report, dated October 7 th, 1890. Dr. Köppen, in briefly criticising this system, agrees that, so far as the vowels are concerned, there can be no doubt that the (practically identical) German and Italian mode of writing them possesses the greatest advantages. But as regards the consonants it is otherwise; the dialectic differences in German are very great, and also through the absence of signs for the "soft" $s$ and sch (French $z$ and $j$ ), through the superfluity of two signs for the same sound in $f(v)$ and $z(c)$ (which latter, moreover, because it $=t s$, is really superfluous), and on account of the monstrous sch, the German consonant system is at a great disadvantage as compared with the French and English.

Through the above-mentioned decisions of the various hydrographical departments, official recognition has been obtained of a system analogous to that which certain prominent German geographers adopted some score or so years since. The author ouly regrets that in these later rules the principles followed by $\mathrm{H}$. Kiepert in the fifties, and Von Richthofen in the seventies, have not been more fully made use of.

Kiepert's rules were, briefly, to employ the German vowel sounds $\ddot{a}, \ddot{o}, \ddot{u}$, the English $y$ for $j, v$ for $w, k h$ for $c h, s$ for the sharp $s(s z), z$ for a soft German $s, s h$ for $s c h$. Corresponding to the latter, $t s h$ was written for the German $t s c h$ (English $c h$ ). A $j$ denoted the French sound of this letter (soft sch). He objected to the English $z h$. Ton Richthofen, in his work on China, also laid down rules for spelling the Chinese words.

The author gives a table which shows the decided similarity between the above systems and those more recent of London, Paris, and Berlin. He laments that the official systems are based on so slight a regard for the doctrine of sound and are so often wanting in clearness in their definitions; also the many different senses in which they use the words "hard" and "soft." Under these circumstances misunderstandings are unavoidable, and are even fostered by these systems.

He next investigates scientifically the various sounds as pronounced in different countries and in certain parts of Germany, and then formulates his proposals for an international (German, English, French) system of orthography for geographical names.

He bases his rules on the undermentioned principles or axioms :

A. That we admit without further alteration everything which is common to the three already-accepted systems of London, Paris, and Berlin.

B. That where the above three systems disagree we can, by disregarding the tendency in which they are formed, choose the best existing, which will ensure the utmost simplicity, economy, symmetry, and intelligibility. Thereby we shall preferably hold to the above-mentioned proposals of Kiepert and Von Richthofen.

C. That in some cases, which the above three systems have still left in doubt, we shall endeavour to amplify them in the same spirit.

The author then lays down rules under the above three headings, A, B, C.

\section{A.- That which is already Agreed on and to be Accepted.}

Rule 1.-Names of countries (states and nations) in which Roman characters are officially used shall be written in the form in which they appear in the latest official publications (maps, books, \&c.) of these states.

* The United States of America virtually accepted the system of the R.G.S. en bloc. 
N.B.-This applies equally to the old Roman character and the alphabets derived from it, the German Gothic character, the Spanish $\tilde{n}$, \&c. As regards colonies, "the orthography of a name in a territory belonging to a civilised power and given in their maps is only followed with respect to their own names and not to native names," which are transcribed according to sound. It is therefore all the more desirable that in the case of colonies and protectorates recently acquired, sar, since 1880, the principle laid down in Rule 3 should be followed.

Rule 2.-For names the orthography and pronunciation of which (in German, French, and English) is of long standing, such rendering shall be maintained in national publications without regard to the rendering which may be in force in the country itself. For example, in England we should still speak of Copenhagen, Brussels, Cologne, \&c., and not of Kjфbenhavn, Bruxelles, Köln, \&c. In publications bearing an international character such forms naturally fall to the ground.

Rule 3.-For all remaining names the true sound as used in the place itself, or in the official language of the state concerned, will determine the mode of orthography.

Rule 4.-An approximation, however, to the sound is all that can be aimed at, and not any exact representation of the minor shades of difference which would involve a far too complicated system of signs.

N.B.-We may define the limits of exactness to be such as would sufficiently express the sound by means which exist in European languages.

Uniformity may be attained by understanding the sound-value of the following letters :-

$$
\begin{aligned}
& a, e, i, o, u \text {, pronounced as in German or Italian. } \\
& b, d, f, k, l, m, n, p, r, t, \quad " \quad, \quad \text { "French, or English. } \\
& g \quad \Rightarrow \quad \text { as } g \text { before } a \text { and } u \text { in French and English. } \\
& v \quad, \quad \text { as in French and English. } \\
& y \quad, \quad \text { as/a consonant, like the German } j \text {. } \\
& \text { sh } \quad " \quad \text { as in English (= German sch, French } c h \text {, } \\
& \text { Italian } s c) \text {. } \\
& \text { th " like the German and Scotch ch, Greek } \chi \text {, } \\
& \text { Spanish } j \text { and } x \text {. } \\
& \text { gh , like the modern Greek } \gamma \text {, Dutch } g \text {, or North } \\
& \text { German } g \text { in "Lage." } \\
& p h \text { is not to be used in the sense of } f \text {. }
\end{aligned}
$$

\section{B.-As to those Points where the three Systems disagree and which Require to be Decided, we must try aNd find the best Solution.}

Rule 5.-In every case where it appears desirable, a second rendering of the name may be placed in brackets; thus all which bears on traditional orthography can be in large characters, and the exact phonetic rendering can be smaller. Thus, for example Kiyef (Kiew), Chieti (Kiéti), Ceuta (thé-uta).

N.B.-As regards Rule 2, a similar course can be adopted if necessary. Ex. Milano (Milan), (Ger. Mailand).

Also with Russian names ending in $o v$ and $e v$ the rendering might be, for example, Tambòf (Tambov), Nikalàyefsk (Nikolaevsk).

No. V.-MAY, 1893.] 
Rule 6.-All compound-sounds, such as $\mathrm{x}$, the German $\mathrm{z}$ and $\mathrm{c}$, the English $\mathrm{j}$ and $\mathrm{cb}$, shall be separated into their constituent parts.

N.B.-The association of sounds varies greatly in different languages; thus the combination $t s$, frequent in German, Russian, and Chinese, is not found in English and French. $T s h$ (German $t s c h$ ) is frequent in English, Italian, and Russian, but rare in German and French. The symbols selected in different languages to denote these sounds vary. The common English compound sound $j$ and Italian $g i$ are wanting in French and Russian, although their constituents exist.

[The author here analyzes and tabulates the various sounds as they can be rendered by European tongues, specifying by figures those sounds which cannot be so rendered, and showing how the three (English, French, and German) systems of orthography provide for them. He shows that the English provide for seven, the French for five out of these seven, and the German only for one which is not provided for by the English or French.]

To fill the gaps he proposes his

Rule 7.-Diacritical signs attached to letters are to be avoided, and only can be permitted (a) when sanctioned by many years usage in an important literature (Ex. ö and $\ddot{\mathrm{ii}}$ in German); (b) when, without them, the pronunciation would be not only less exact, but unrecognisable.

Rule 8.-In the case of names spelt according to sound, each letter must be distinctly pronounced, with the exception that two different vowels coming together may form a diphthong, and amongst consonants a few simple sounds will be represented by pairs of letters.

N.B.-This rule corresponds to Rule 7 of the British system, in which, however, the consonants with $h$ and the $n g$ are omitted. Rules 1 to 4 correspond to the similar numbers in the British scheme. To complete the omissions in the three schemes, the author proposes a $t h, d h, z h, n g$ (as in "Lunge"), $\ddot{u}$, and $\ddot{o}$.

As regards accents, the English and German systems only admit one acute accent "where there is a very decided emphatic syllable which affects the sound of the word." The French do not mention such, but use a circumflex accent to lengthen a vowel. Doubling a vowel is not admitted except in special cases such as "Nuulua." To shorten a vowel the English system doubles the consonant which follows it, but the Germans do not legislate for either lengthening or shortening vowels. The German hydrographical rules use $\ddot{a}$ and $\stackrel{a}{a}$ to denote the open $e$ and $o$.

Rule 9.-A grave accent should denote an accented open vowel, an acute accent an accented closed vowel, and a circumflex a vowel pronounced long (accented more or less), also a doubling of the consonant following a vowel will denote a pronounced short vovel; should there be any doubt as to the accent, then the vowel should be left unaccented.

Examples of "wide" vowels are those as in Tisch, Tusch-to be written with $i$ and $i$ if the accent is on them.

\section{C.-Ponnts Left Untouched in the Three Systems.}

(1) For the sound of the Russian a (Polish $y$, Roumanian $\hat{\imath}$ and $\hat{a}$ ) he recommends the symbol $\ddot{i}$.

(2) For the nasal vowels (French sound $a n, o n, i n, u n$ ) he proposes the Portuguese equivalents $\tilde{a}, \tilde{o}, \tilde{e}, \tilde{\ddot{o}}$.

(3) Palatal consonants: In order to obtain the $j(y)$ sound, which in certain lan- 
guages appear between a consonant and the vowel following in such words as Rjasan, Dnjestr, he introduces a $y$, and legislates for it as follows in

Rule 10.-A y after a consonant is to be pronounced as if dissolved with it, and serves as an index of the palatal sound of the consonant. This is, however, indispensable before $\mathrm{a}, \mathrm{o}, \mathrm{u}$, and è ; in other cases it would be used when by so doing it would simplify the case.

N.B.-This rule would mainly be used for transcribing Russian words.

A few examples out of those cited by the author will show how this rule would be applied.

French.-Gascogne (gaskòny), Bretagne (brötány).

Itatian.-Bologna (bolònnya), Legnago (lenyâgo).

Portuguese.--Minho = Spanish Miño (mínyo).

Russian.-Ryazán (ryazány), T'vér (tyvéry), Khárkof (kháryk'f).

Rule 11.-When two letters, which denote, when joined together, a diphthong or a simple consonant sound, are pronounced separately, they should be joined together with a hyphen (-). Example, Da-urien.

The author by means of a table compares the proposed international geographical alphabet with the "standard alphabet" of Lepsius and that described in the "Maitre Phonétique,' by P. Passy, with which it generally agrees.

The international alphabet as proposed by the author is as follows:-

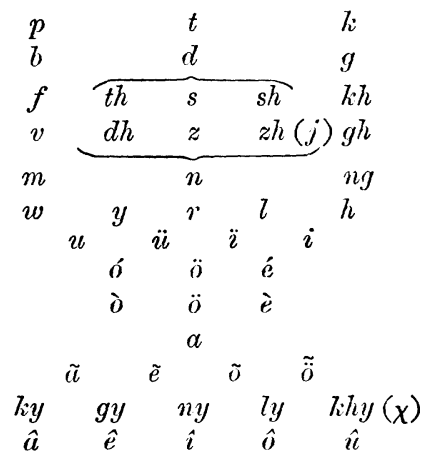

Having now arrived at the international alphabet, the production of which was aimed at, the author proposes the 12 th and last rule.

Rule 12.-For purposes of transcription, speaking generally, it is necessary that each sound shall be expressed by the letter which most closely represents it, without regard to grammar, derivation of words, and the traditional orthography in the language immediately concerned.

The above paper was completed in May 1892 and laid before the committee appointed by the German Kolonialrath to draw up a system for the pronunciation and orthography of geographical names in the German protectorates, which resulted in the rules (approved and adopted by the German Government) to which attention was drawn in the Proceedings R.G.S. of November, 1892. 
The orthography as then adopted would, if arranged in a table similar to that given above (proposed by Dr. Köppen), be as follows-

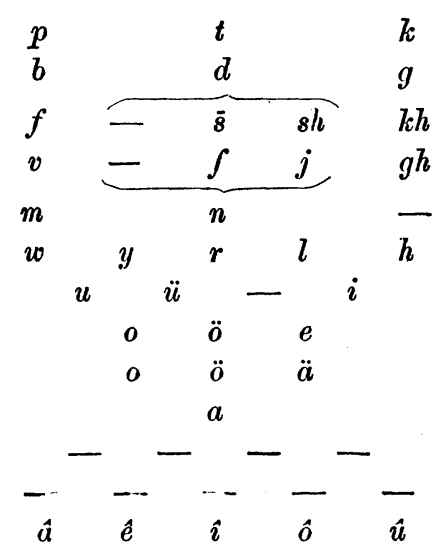

Dr. Köppen claims that a glance at the two tables will show that in most cases the committee agreed with his proposals; and he indicates and criticises those points as to which the committee did not accept his views (these are shown by the blanks in the latter of the two tables).

In a footnote, p. 35, Dr. Köppen alludes to the Proceedings R.G.S. of November last, wherein I reviewed the new German rules and compared them with those brought out in 1885 by the R.G.S. (and revised in 1892).

Though I cannot but feel honoured that my few humble criticisms of the points of difference between the English and German systems should have been deemed worthy of the attention of so distinguished an authority as Professor Köppen, I regret that they have left such a poor impression on him as his remarks in the above-mentioned footnote would seem to imply.

Still, may it not be possible that we are considering the subject of orthography of geographical names from different standpoints? The English system as drawn up by the R.G.S. was a system of "orthography for native names of places," and, strictly speaking, its object was to secure uniformity in spelling the names of outlandish places in our various colonies and elsewhere, of which the languages are legion and complicated. For that reason our two first rules especially lay down that no change is made in the spelling of foreign names in countries which use Roman characters, nor is any change made in the spelling of such names not written in Roman character, but which from long usage have become familiar to English readers.

Our rules, in fact, like the new German rules, are for our protectorates or Schutzgebieten. Therefore it is undoubtedly important that as the English and German protectorates are in many cases conterminous, 
the orthographical rules of the two countries should be as nearly identical as possible. The principal value of such rules is for purposes of official correspondence, and above all for hydrographical sailing directions, and charts, and for maps. As one who for several years has had to do with map compilation, I naturally look to such rules from the point of view of the cartographer, and unhesitatingly maintain that any system of spelling which contains the quantity of diacritical signs, and arrangements of letters as does Dr. Köppen's, defeats itself and becomes impossible for the cartographer, or in fact for any practical use.

Dr. Köppen has produced with infinite study and care a system for an international rendering of geographical names, as near perfection as such a system could probably be got; but in order to embody every possible sound which can be thought of it has necessarily become complicated, and is a language of itself. It is far more extensive than are the English and French rules, in which simplicity and avoidance of diacritical signs is the key-note. It deals with all geographical names; ours and the new German system only deal with native place-names.

The subject is, however, of such importance that, as Dr. Köppen says, it is sincerely to be hoped that the next international geographical congress will deal with it. If a small international committee of English, American, French, and German experts were appointed to thrash out the question, it must result in good; and the valuable paper by Dr. Köppen, of which I have only been able to give a précis, and which deserves to be read in its entirety, could not fail to be of the greatest assistance to such a committee.

\section{THE ACROPOLIS OF SUSA.*}

By Major-General Sir FREDERIC GOLDSMID, K.C.s.I., C.B.

Favoured by the patronage and support of the French Government, M. Marcel Dieulafoy has, under the above title, produced a handsome and remarkable volume treating of the contents of mounds in southwestern Persia, to which the attention of Biblical students has been especially drawn during the second half of the fast-closing century, though by no means ignored by earlier travellers and explorers. But the result of systematic excavations, carried on within the last decade of years, has a more cosmopolitan significance than is exemplified in substantial relics and valuable additions to the thesaurus of the Louvre. It is further notably displayed in the ventilation and propagation of archæological and ethnological theories, which, if they do not always

* 'L'Acropole de Suse; d'après les Fouilles exécutées en 1884, 1885, 1886.' Sous es auspices du Musée du Louvre. Paris, Hachette, 1893. 